\section{Barriers to Extracurricular Reading Promotion in Academic Libraries}

\section{Julie Elliott, Guest Columnist}

Correspondence concerning this column should be addressed to Barry Trott, Adult Services Director, Williamsburg Regional Library, 7770 Croaker Rd., Williamsburg, VA 23188; e-mail:btrott@mail.wr.org. Julie Elliott is Assistant Librarian, Coordinator of Public Relations and Outreach, Franklin D. Schurz Library at Indiana University-South Bend.
In her 2007 column "Academic Libraries and Extracurricular Reading Promotion" (RUSQ 46:3), Julie Elliott looked at the history of Readers' Advisory (RA) and extracurricular reading in academic libraries, and made a cogent argument for the reintegration of readers' services into academic libraries. In the following column, she expands on this concept, exploring some of the barriers that are faced in offering or expanding RA services in colleges and universities. As in her earlier article, Elliott surveys practitioners in academic institutions where RA is not currently practiced in any focused fashion. She outlines the issues surrounding establishment of leisure reading promotion and makes suggestions for ways to take advantage of existing collections as well as to work collaboratively to expand the opportunities for promoting and supporting extracurricular reading among college and university students.

Elliott organizes the One Book, One Campus events at Indiana University-South Bend as well as the library's speaker series. She is an active participant in the promotion of RA services, and she serves on RUSA's Collection Development and Evaluation Section (RUSA CODES) Readers' Advisory Committee. Elliott also edits the "By the Book" column for Public Libraries and currently serves on ALA's Notable Books Council.-Editor

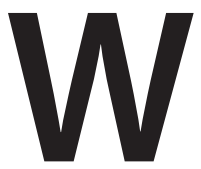
hile I noted in my earlier article, "Academic Libraries and Extracurricular Reading Promotion," (RUSQ 46:3), that many colleges are finding ways to promote reading to their students, many students are not taking advantage of these services. A study by the National Endowment of the Arts (NEA) found that 65 percent of college freshmen spend less than an hour a week on leisure reading, and by the time they are seniors, one in three of them will do no leisure reading at all. ${ }^{1}$ The Bureau of Labor Statistics' 2007 American Time Use Survey found that, on weekends, people aged 15 to 19 spent approximately 16 minutes reading for pleasure. Adults aged 20 to 24 spend approximately 7 minutes on the weekend doing leisure reading. ${ }^{2}$ This is a significant drop from the 2006 survey, where adults aged 20 to 24 were spending 14 minutes reading for pleasure during the weekends. ${ }^{3}$

With new technologies creating myriad ways for young adults to get their information, why should reading books outside of their curriculum matter at all? One reason is that literacy rates for college students are on the decline. A 2005 survey done by the National Center for Education Statistics (NCES) found that the average prose literacy scores for adults with bachelor's degrees had dropped 11 points since 
1992; adults with graduate degrees fared worse, dropping 13 points. Prose literacy is defined as "[t]he knowledge and skills needed to perform prose tasks (i.e., to search, comprehend, and use information from continuous texts). ${ }^{.4}$ The same survey found that only 31 percent of current college graduates could be considered "proficient" in reading prose, and only 41 percent of those with graduate degrees would be considered "proficient." ${ }^{5}$ Being "proficient" in reading prose meant that a person could "compare viewpoints in two editorials." Furthermore, 3 percent of college graduates in 2003 were considered to have "below basic" skills in prose literacy. ${ }^{\top}$

Colleges should be concerned with declining literacy among their graduates because college graduates who are considered "proficient" in prose literacy are more likely to be employed than those who have only basic literacy skills. ${ }^{8}$ In addition, a study by the NEA found that active readers are more likely to vote and to volunteer in their community. ${ }^{9}$

Every college wants to graduate students who are proficiently literate, can successfully gain employment, and are civically engaged. It should be noted that there are barriers that can keep college libraries from adding extracurricular reading promotion to their already lengthy list of priorities. It should also be noted that students did not develop reading and literacy issues through coming to college, but because of problems throughout the U.S. K-12 education system. No college library director or dean is going to tell you that they want to graduate students who cannot compare and contrast two newspaper editorials, even if they do not believe that leisure reading promotion is the answer. Many academic library directors and deans interviewed in this article would like to promote leisure reading, but other realities intrude. This article will discuss the reasons academic library directors and deans are sometimes unable to promote extracurricular reading to their students, provide suggestions for ways that public libraries could reach out to their local college libraries, and examine potential future areas of research on the subject.

\section{THE SURVEY}

A survey of ten questions was created on SurveyMonkey, and an invitation to library deans and directors whose libraries do not promote extracurricular reading was sent to the Collib-L and Libadmin-L discussion lists. Directors and deans of the 111 academic libraries belonging to the Association of Research Libraries received e-mails asking them to participate in the survey if their library did not promote extracurricular reading promotion. Thirty-eight people answered the survey, but not all answered every question. The survey was confidential, with certain questions allowing for further comment. If participants agreed to be contacted for further questions, they consented to be quoted (see appendix B, "Further Interview Questions to Deans and Directors"). The full results of the survey can be found at www.surveymonkey.com/s.aspx ?sm=6VDgeRC5dRGQ2O7bV5qshA_3d_3d. The text of the survey and study information can be found in appendix A.
There were some potential flaws with the survey and survey invitation. The fact that the title of the survey was "Barriers to Extracurricular Reading Promotion in Academic Libraries" turned away some potential respondents, who communicated to me that they would not take a survey that implied something negative. The fact that the survey questions asked why the libraries were not doing something also may have turned away many potential respondents, as sixty-seven people started the survey by answering question 1 ("Have you read the form and agree to take the survey?"), but thirty of those respondents did not go on to answer question 2. Rephrasing some survey questions could lead to a larger number of results. Question 2 included a definition of extracurricular reading promotion that may have led some potential respondents to abandon the survey if they found their libraries' activities fit the definition. In future research, that definition will be included in the survey invitation. While starting with a smaller number of potential respondents than in my previous survey (Library Directors and Deans Who do not do Academic Reading Promotion in their Libraries Versus Any Academic Librarian), the number of respondents is disappointing-unless of course it means that more libraries are doing extracurricular reading promotion than in the past.

\section{BARRIERS TO EXTRACURRICULAR READING PROMOTION}

The main reason cited for not doing extracurricular reading promotion was budget issues, with 70 percent responding that it was an issue and 31 percent noting that it was the number one issue impeding reading promotion. One survey respondent stated,

My library does not have sufficient funding to acquire everything we should to support teaching, learning, and research. I would not be a good manager of my budget if I used some of my insufficient funding to acquire materials that are available at the public library.

Staff issues were another reason cited, with 65 percent listing it as an issue, and 25 percent citing it as the main issue. From the anonymous comments, there appear to be two types of staff issues: a lack of staff and a lack of interest from staff. "All decreases in services and services never delivered [are] nearly always about staff downsizing, of which there appears no end," one respondent replied. "I would be willing to support activities of this type, but nothing all that creative has been suggested by library faculty/staff," wrote another respondent. One potential solution to both types of staffing problems is the use of volunteers, though there are challenges here as well. "It is hard to find staff time to put toward this with being understaffed already and we have tried unsuccessfully for years to find volunteers to do things such as this," one respondent wrote. 


\section{READERS' ADVISORY}

Another major concern was whether students would actually make use of any leisure reading provided. Phyllis Bratton of Jamestown College noted,

It is always important for librarians of any stripe to promote reading. However, on a college campus the students are already going to class, studying and researching, and working an enormous amount of hours to finance their educations. Reading is more laborintensive than sitting in front of a television and less in-the-moment than social networking, so I do not believe that promoting reading even more would be terribly successful. ${ }^{10}$

Bratton has noticed at her college, however, that there has been an increase in requests for leisure reading, which her library is working to meet through low-cost methods: "We have started a book exchange of popular materials in the lounge-take any book you like as long as you leave oneand that has worked fairly well."11 Other academic libraries have not been so fortunate: "We are a commuter campus and find that students are hard to motivate beyond their assignments," one respondent noted.

Some library deans and directors skip extracurricular reading promotion not because of any outside barrier, but because they do not believe in it. Slightly more than 11 percent of those surveyed stated that they do not believe that extracurricular reading promotion is part of an academic library's mission, and two respondents stated that they would never promote extracurricular reading at their library. "[An] academic library is to support the curriculum. Popular reading is for public libraries," one respondent noted. Another noted:

Assignment of staff to this activity in a research institution takes them away from direct service to students and faculty. The need to transform academic libraries in our changing environment strikes me as more important than reading programs.

Most respondents were more positive about leisure reading promotion, even if they do not have the resources to pursue it. Some library deans and directors who took the survey acknowledged that they do some extracurricular reading promotion, but would do more if budget and staffing allowed. Ways that these libraries do extracurricular reading promotion for their students are discussed in the next section.

\section{LOW-COST LEISURE READING PROMOTION}

One method of promoting reading without spending additional funds is promoting popular titles in the collection that also support the curriculum. A faculty member at Indiana University-South Bend noted that many college students choose young adult titles for leisure reading. Many universities teach courses in young adult literature, and therefore already have books in the collection for the curriculum that could also be promoted to students for leisure reading. Bratton stated, "We have a large curriculum library and as such have a collection of books which appeal in some respects to this age group-Harry Potter, Christopher Paolini's books, Tolkein, C. S. Lewis, the Twilight series, and so on. These circulate quite a lot." ${ }^{2}$ Another respondent noted the importance of getting students hooked on young adult titles:

Any mention of a book club or something official they bring up the "but our students are too busy to read"yeah right-I got half our student workers hooked on the Twilight series this year, and they're all pretty typical as to courseload, etc.

Continuing the theme of making use of materials already purchased for curricular use, new title displays are another method the academic librarians surveyed used to promote leisure reading. The most common type of extracurricular reading promotion noted in the survey was a paperback exchange service.

\section{HOW CAN PUBLIC LIBRARIES HELP}

Like academic libraries, many public libraries are understaffed and underfunded. However, there are ways public librarians can reach out to their local academic library communities and, with minimal effort, provide valuable assistance in promoting extracurricular reading among college students. Many college students, especially those at state or branch campus colleges, tend to settle down in the area where they went to school. By helping local colleges promote leisure reading, public librarians not only assist their academic library colleagues, but also lay the foundation for the next generation of readers at the public library. Public or academic librarians interested in seeing how they can work together to nurture the next generation of adult leisure readers should contact each other and see if there are ways they can work together to meet their local college students' leisure reading needs.

Perhaps the easiest way to work with your local academic libraries is to allow students at local colleges to check out items at your library. If your library already provides library cards to local college students, you may want to speak to your local academic libraries about making booklists and other promotional materials from your library available to their students. These items have already been created for your library, and by making them available to your local college libraries you would be reaching a new audience as well as helping a library that either does not have the titles in question or the staff time to create such reading lists.

Does your library have older romance, western, or science fiction titles that have been weeded from the collection and are not considered suitable for your Friends of the Library book sale? Consider donating them to your local academic library so they may start a paperback exchange program.

If your public library has a "One Book, One Community" program, consider reaching out to your local academic librar- 
ies to see if they would be willing to help host a speaker or hold a book discussion on campus. College campuses often will have larger auditorium spaces that can help accommodate larger crowds. Edward O'Hara, library director at Western Connecticut State University, noted that their recent first collaboration with the Danbury Public Library on the One Book, One Community program was a very positive experience. Since the university auditorium had more seating than the public library's, the author talk was held at the campus, with more than seven hundred people in attendance, approximately three hundred of them students. "We got a lot of response from the community-people who will become friends of the university because of the experience," O'Hara noted. $^{13}$

There are times however, when an academic library may not want direct help from their local public library. "[We have] excellent public library services, [but we] should not create confusion between public libraries and large academic libraries in urban metropolitan areas," suggested Cheryle Cann, head of the Ward E. Barnes Library at the University of Missouri-St. Louis. ${ }^{14}$ Reaching out to your local academic libraries (and vice versa) will give you an idea whether any kind of collaboration would be feasible.

\section{WHAT'S NEXT}

There is a lot to be examined when thinking of college students and leisure reading. Perhaps the most obvious is to go directly to the students themselves and find out what would encourage them to read more for pleasure, or to determine whether there is any desire for them to do leisure reading at all. In its 2007 overview of studies of adult reading habits, "To Read or Not to Read," the NEA suggested that more studies are needed to examine the "effectiveness and costs and benefits of programs to foster lifelong reading and skills development" as well as studies to examine the "effects of electronic media and screen reading" in young adult reading development. ${ }^{15}$ Do the Internet, instant messaging, reading blogs, games, and other electronic media, which many claim have replaced reading, have a detrimental effect, or is that exaggerated? Studies by groups like the Kaiser Family Foundation are beginning to examine whether electronic multitasking has had an effect on young adults' ability to focus on activities such as reading books, and no doubt more studies and surveys on the topic will be published in the next decade, giving a better understanding of the relationship between new technologies, literacy, and leisure reading. ${ }^{16}$ If the prose literacy skills of our college graduates are eroding, are they being replaced with other skills, and do those new skills make up for what is being lost in the critical thinking abilities that come from, for example, being able to read and compare two newspaper editorials? It will be interesting to see if the NCES publishes another study in the next ten years and whether it shows that college graduates' prose literacy skills have continued to drop or if they stabilize. Furthermore, thought should be given as to when students lose interest in reading for pleasure-it does not necessarily begin in college. At what point does it start, and is it related to the increasing lack of school librarians in the K-12 system? How can libraries at all levels—public, school, and college—work together to bring students back to reading? Librarians interested in researching leisure reading and its effects should also consider reaching out to the faculty at their local colleges, who may also have an interest in the subject and may be able to use their expertise to help design a research study. I know I am always looking for collaborators on the subject, and anyone interested can contact me atjmfelli@iusb.edu.

We should decide if leisure reading is a skill worth preserving for future generations, and, if it is, librarians from public, academic, and school libraries should begin talking with each other about ways to promote it-through new technologies, outreach, or other methods. Many librarians, even if they are not able to actively promote it at their libraries, do believe that, despite the dire reports about adult leisure reading in recent years, it is actually making a comeback: "I think that reading is coming back as a leisure activity," stated Bratton. "We are certainly busier than we have been for years." To keep the comeback going, let's find a way to work together to use our limited resources for the greatest good.

\section{References}

1. National Endowment for the Arts, Research Report \#47: To Read or Not to Read (Washington, D.C.: NEA, 2007).

2. U.S. Department of Labor, Bureau of Labor Statistics, Economic News Release, Table 11. Time Spent in Leisure and Sports Activities for the Civilian Population by Selected Characteristics, 2007 Annual Averages, www.bls.gov/news.release/atus.tll.htm (accessed Feb. 21, 2009).

3. U.S. Department of Labor, Bureau of Labor Statistics, Economic News Release, "American Time Use Survey News Release, American Time Use Survey-2006 Results," www.bls.gov/news.release/ archives/atus_06032008.htm (accessed Feb. 21, 2009).

4. U.S. Department of Education, National Center for Education Statistics, A First Look at the Literacy of America's Adults in the 21st Century, 2, http://nces.ed.gov/NAAL/PDF/2006470.PDF (accessed Feb. 21, 2009).

5. Ibid., 14, table 7 .

6. Ibid., 3 .

7. Ibid., 15 , table 8 .

8. Ibid., 16, figure 17.

9. National Endowment for the Arts, Research Report \#47.

10. Phyllis Bratton, e-mail to author, Dec. 9, 2008.

11. Ibid

12. Bratton, e-mail to author, Dec. 9, 2008.

13. Edward O'Hara, phone interview with author, Dec. 15, 2008.

14. Cheryle Cann, e-mail to author, Dec. 10, 2008.

15. National Endowment for the Arts, Research Report \#47, 94.

16. Laura Levine, Bradley Waite, and Laura Bowman, "Electronic Media Use, Reading, and Academic Distractability in College Youth," CyberPsychology and Behavior 10, no. 4 (2007): 560-65. 


\section{READERS' ADVISORY}

\section{APPENDIX A}

IRB Study Form and Survey Questions

IUSB IRB Approved

Approval Date: October 9, 2008

Expires: October 8, 2009

\section{INDIANA UNIVERSITY SOUTH BEND \\ STUDY INFORMATION SHEET \\ Barriers to Extracurricular Reading Promotion in College Libraries \\ IRB \#08057}

You are invited to participate in a research study involving barriers to readers' advisory services in college libraries.

\section{INFORMATION}

If you agree to participate you will be one of approximately 50 to 100 subjects who will be participating in this research. You will be asked to answer 15 questions regarding the lack of readers' advisory services at your library and your own attitudes toward RA and reading. The survey will take approximately 5-10 minutes to complete. If you agree to be contacted for a further interview, this will be conducted either via e-mail or telephone, and will take approximately 20-30 minutes to complete.

\section{BENEFITS}

While there is no direct benefit to you from participating in this study, I hope to raise the awareness of barriers to extracurricular reading programs and readers' advisory in academic libraries.

\section{CONFIDENTIALITY}

Unless you have given contact information for an interview the survey will be anonymous, although any information transmitted across the Internet could potentially be seen by others. If you have given your contact information it will be erased from my computer after the interview has taken place. If you are willing to be interviewed further, please provide your contact information at the end of the survey. If you are interviewed, you may be quoted in any presentation or publications that result from this research. I will ask your permission at that time if it is OK to use your name along with the quote.

\section{CONTACT}

If you have any questions at any time about the study or the procedures, you may contact Julie Elliott at Library 109, Indiana University South Bend, 1700 Mishawaka Ave., South Bend, IN 46634, (574) 520-4410, jmfelli@iusb.edu.

If you feel you have not been treated according to the descriptions in this form, or your rights as a participant in research have not been honored during the course of this project, you may contact the Indiana University South Bend Institutional Review Board for the Protection of Human Research Subjects, 1700 Mishawaka Ave., A247, South Bend, IN 46634, 574-520-4181, by e-mail at sbirb@iusb.edu.

\section{PARTICIPATION}

Your participation in this study is voluntary. If you decide to participate, you may withdraw at any time without penalty. Once your survey has been submitted to me, it cannot be returned since the surveys are anonymous. You must be 18 years of age to participate in this study.

1. Have you read the form and agree to take the survey?

$\square$ Yes, I have read the form and agree to take the survey.

No, I do not agree to take the survey.

2. Why does your university library not actively promote extracurricular reading and readers' advisory? Please select all that apply.

Readers' Advisory: where a librarian or staff member helps readers choose what books to read, provides suggestions for recreational reading, etc.

Other examples of extracurricular reading promotion: staff picks, displays, McNaughton collection, and One Book, One Campus programs 
Budget issues

口. Staff issues

Concerns that if staff or money are used on something perceived as nonacademic it will leave library open to budget cuts

- Space concerns

- Image concerns (idea of academic libraries and librarians being too closely identified with books and reading)

- Feel students would not actively participate

- Do not see extracurricular reading as part of academic library's mission

Additional comments on this question:

3. Of the reasons for not actively promoting extracurricular reading selected in the question above, which reason is the main one? Please select one answer only.

口 Budget issues

- Staff issues

C Concerns that if staff or money are used on something perceived as nonacademic it will leave library open to budget cuts

- Space concerns

- Image concerns (idea of academic libraries and librarians being too closely identified with books and reading)

$\square \quad$ Feel students would not actively participate

- Do not see extracurricular reading as part of academic library's mission

Additional Comments on this Question:

4. Which of the following would need to happen at your university in order for you to consider actively promoting extracurricular reading at your library? Please choose all that apply.

- Significant increase in budget

- Staff increase or an active library volunteer program

- Collaboration with local public library

- Students requesting service

- Administrative support for extracurricular reading

- Administrative request for extracurricular reading promotion

I I would never actively promote extracurricular reading at my library

Additional Comments on this Question:

5. Of the reasons why you would begin promoting extracurricular reading at your library that you selected above, which reason would be the most influential to you? Please select one answer only.

a Significant increase in budget

- Staff increase or an active library volunteer program

- Collaboration with local public library

- Students requesting service

- Administrative support for extracurricular reading

- Administrative request for extracurricular reading promotion

I I would never actively promote extracurricular reading at my library

Additional Comments on this Question:

6. Has your library ever actively promoted extracurricular reading?
口 Yes
ㄱo

7. Your university is primarily:
a Commuter
๑ Residential

volume 48 , issue 4 | $\underline{345}$ 


\section{READERS' ADVISORY}

8. The highest degree your university grants is:
a Doctorate
- Master's
B Bachelor's
a Associate's

9. Please check the answer which best matches your opinions on the following questions
Extracurricular reading promotion should be a priority for academic libraries
$\square$ Strongly Agree $\square$ Agree $\square$ Disagree $\square$ Strongly Disagree $\square$ No Opinion
Strongly Agree
$\square$ Agree
$\square$ Disagree
$\square$ Strongly Disagree
No Opinion
$\square$ Strongly Agree
$\square$ Agree
$\square$ Disagree
$\square$ Strongly Disagree
$\square$ No Opinion
Strongly Disagree
$\square$ No Opinion
Extracurricular reading is a public library issue
Extracurricular reading is important for
college students
Encouraging reading is an academic
librarian's role
$\square$ Strongly Agree
$\square$ Agree $\square$ Disagree $\square$
I would do more to promote extracurricular reading if it was written into my job
$\square$ Strongly Agree
$\square$ Agree
$\square$ Disagree
$\square$ Strongly Disagree
No Opinion
description and I had university
administrative support to do so
I would be interested in collaborating with my local public library on extracurricular reading
$\square$ Strongly Agree
$\square$ Agree
$\square$ Disagree
$\square$ Strongly Disagree
$\square$ No Opinion promotion
I read books for fun often (more than $1 \mathrm{a}$ week)
I read books for fun sometimes (approx. 1 a month)
I rarely read books for fun (less than $1 \mathrm{a}$ month)

\begin{tabular}{|c|c|c|c|c|}
\hline$\square$ Strongly Agree & $\square$ Agree & $\square$ Disagree & $\square$ Strongly Disagree & $\square$ No Opinion \\
\hline$\square$ Strongly Agree & $\square$ Agree & $\square$ Disagree & $\square$ Strongly Disagree & $\square$ No Opinion \\
\hline$\square$ Strongly Agree & $\square$ Agree & Disagree & Strongly Disagree & $\square$ No Opinion \\
\hline
\end{tabular}

10. If you would be willing to be interviewed for this study and to be possibly quoted in the article, please provide your contact information below:

Name \& Job Title:

Phone (please specify work or home):

E-mail:

I prefer to be contacted by: phone e-mail

\section{APPENDIX B: FURTHER INTERVIEW QUESTIONS TO DEANS AND DIRECTORS}

1. Do you believe that the promotion of extracurricular reading should be a priority for academic libraries?

2. Why do you think the promotion of extracurricular reading is not promoted more in academic libraries?

3. Would you be interested in collaborating with your local public library on extracurricular reading promotion? Would you consider meeting with your local public library director or their readers' advisory or reference department to discover ways that they could bring their readers' advisory services to your library and students?

4. Does your book collection have a strong circulation rate? Is your book budget stable, or is it decreasing due to serials costs? How much of a barrier is the budget to extracurrricular reading promotion in your library?

5. Does your area or university have a "One Book" type program? If it does, would your library consider hosting an event or book discussion for the program at your library? Do you think your students would participate?

6. Would you consider low-cost extracurricular reading promotions such as a paperback exchange with initial titles donated from staff members?

7. The University of Houston Libraries have several endowed book funds, one of which, the Jack E. Wilson Endowment, is for books of humor. Does your library or your university's development office seek endowments for book collections, and if yes, would this be one way that your library might consider building a collection of popular literature?

8. Anything else you would like to add?

Thank you very much for your response. 